\title{
“CONCEPTUAL DIRECTIONS OF HIGHER EDUCATION SYSTEM IMPROVEMENT"
}

\author{
Mamayunus Karshibaevich Pardaev \\ - Professor, Samarkand Institute of Economics and Service, Candidate of Economic Sciences, tel: +99897 7930048. Email: \\ pardaev_mk@mail.ru. 104000 Samarkand, st. A.Temura 9
}

\section{Babanazarova Sevara Abdinazarovna}

- Senior Lecturer, Samarkand Institute of Economics and Service, tel.: +998 913530720. E-mail: Babanazarova_sevar@mail.ru 104000 Samarkand, st. A.Temura, 9.

\begin{abstract}
:
The article discusses the conceptual directions of improving higher education within the framework of the tasks identified in the Address of the President to the Oliy Majlis on January 24, 2020. To implement one of the tasks set by the President for the formation and development of "Higher Education Without Corruption", the model "Higher Education" was developed without corruption "and the ways of its formation are shown. A number of conceptual directions of a radical reform of higher education have been developed. They were based on the introduction of strict discipline in higher education institutions (universities), ensuring the compatibility of theory and practice in the educational process in universities, training based on special orders of entrepreneurs, and solving the problem of commercialization of intellectual property. It was also argued that the structure and order of teaching in the higher education system should be changed, that current programs are mainly preparing to become specialists in order to work in some work establishments, in enterprises and in tomorrow's institutions, and not fully meet today's requirements. The issues of gradual transition of universities to academic and financial independence were also considered.
\end{abstract}

Keywords:

education, educational services, higher education, corruption, non-corruption higher education, science, enlightenment, digital economy, digital education.

Article Received: 18 October 2020, Revised: 3 November 2020, Accepted: 24 December 2020

\section{INTRODUCTION}

In the Address of the President of the Republic of Uzbekistan to the Oliy Majlis, he identified priorities for improving higher education. After all, Uzbekistan has entered a new, rapid stage of development. At this stage, the level of development does not occur spontaneously. First of all, we need appropriate personnel, equipment and technologies. This is stated in the Address of the President of the Republic of Uzbekistan Shavkat Mirziyoyev to the Oliy Majlis on January 24, 2020: Where there is no knowledge, there will be backwardness, ignorance and, of course, misguidance"[1]. Now let's look at the issue realistically. What is our current situation, does the contribution and role of qualified personnel in society meet the demand? Of course, it is difficult

to answer these questions with great satisfaction. Today, just over $35 \%$ of the working population has a higher education. The remaining 65.0 population are people with secondary special and secondary education. Given that $80-90 \%$ of the working age population in developed countries has higher education, there is no need to comment on the situation in our country. Due to this, intensive work is being done to create all the conditions for the education of our enthusiastic young people, who have a fire in their hearts that they will get a higher education, work on themselves and become educated. Previously, the coverage of high school students with higher education was even less than $10 \%$. In 2019, that figure rose to $20 \%$. According to the statement, the goal is to increase the coverage of higher education graduates by at least $25 \%$ by 2020 and by $50-60 \%$ in the future.

In his address to the parliament, the head of our state said, "As the wise men of the East say, 'The greatest wealth is intelligence and knowledge, the greatest heritage is a good upbringing, the greatest poverty is ignorance!' 
That is why the acquisition of modern knowledge, true enlightenment and high culture must become a constant vital need for all of us. He said. Indeed, today everyone should strive to become a true enlightened and highly cultured person who has mastered modern knowledge. Such a habit, as the head of our state stressed, must become a constant necessity. Our breathing of air, our daily nourishment is a continuous vital need. In the same way, striving to be truly enlightened and cultured must become a part of our daily lives. After all, in today's rapidly changing world, the acquisition of knowledge, the pursuit of true enlightenment, and the acquisition of a high culture have become a process that cannot be delayed for a moment. Indifference to this can be assessed as an enemy, first of all, of oneself, of progress and, finally, of society. This situation should become a daily necessity not only for young people, but for all sane people, regardless of age.

\section{ANALYSIS OF THE LITERATURE ON THE SUBJECT}

Due to the peculiarities of educational services in our country, a number of our scientists are engaged in one or another aspect of this issue. These include S.S.Gulamov, M.Q.Pardaev, Q.J.Mirzaev, K.Kh.Abdurahmanov, A.Sh.Berdimuradov, O.M.Pardaev, Z.Adilova, B.Khonturaev, B.I. Isroilov, E.F.Gadoev, M.Saidov, A.Xaliqov, Ya. Mamatova, S. Sulaymanova [2] etc. are engaged. The works of these scholars cover general aspects of the service sector, including educational services. However, in the work of these scientists, not enough attention has been paid to reforming, digitizing and improving the education system in line with today's requirements.

\section{RESEARCH METHODOLOGY}

He used the methods of logical analysis, cause and effect, analysis and synthesis, induction and deduction as a methodological basis in the process of developing conceptual directions for improving the organizational and economic mechanisms of its implementation, based on the objective needs of education services today. Indeed, to ensure the rapid development of the economy, highly qualified personnel are needed, and the education system will need to be improved to train them accordingly. This will be achieved through reform of the education system. Due to this, the main issues of the work and their directions were covered using the methods of logical analysis.

\section{ANALYSIS AND RESULTS}

In order to fully meet today's requirements, in order to achieve rapid development, as noted by the President in his address to parliament, "... it is necessary and necessary to acquire digital knowledge and modern information technology. This allows us to take the shortest path to the ascent. Because today, information technology is penetrating deep into all spheres of the world" [3]. These words of the head of our state determine the directions of reforming the higher education system.

In addition, the Decree of the President of the Republic of Uzbekistan PF-5847 "On approval of the Concept of development of the higher education system of the Republic of Uzbekistan until 2030", adopted on October 8, 2019. The document states that "identification of priorities for the systemic reform of higher education in the Republic of Uzbekistan, raising the process of training highly qualified personnel with modern knowledge and high moral qualities, modernization of higher education, social education based on advanced educational technologies and development of economic sectors " [4]priorities were identified. It is obvious that the implementation of these large-scale tasks requires the active participation of not only the Ministry of Higher and Secondary Special Education, but also our entire nation. Because the development of society depends on education, everyone is interested in the high efficiency and quality of education. 
Just as a bird needs two wings to fly, so a person needs two wings - faith and knowledge - to rise to higher levels. Nobel laureate Albert Einstein once said, "Science without religion is dead, religion without fan is lame." During the period of atheism in our country, one wing of human perfection, that is, faith, was cut off. To be learned, one must not believe, they were propagated as contradictory concepts. Everyone knows what happened. There is an old saying, "If you want to be happy in this world, do business. If you want to be happy in this world, do prayer. If you want to be happy in both worlds, do science." That is why it is obligatory for every Muslim to seek knowledge in the holy books.

As noted in the Address of the President of the Republic of Uzbekistan Shavkat Mirziyoyev to the Oliy Majlis on January 24, 2020, at a time when religious and secular sciences do not contradict each other in our country. In order to accelerate the work we have begun to shape the economy and bring it to a new, modern level, I plan to launch in our country by 2020 "Science, Enlightenment and Digital Economy. sodiyotni development ", as the name suggest" [5], he pointed out. Science and enlightenment are not only about the "secular" sciences that we recognize, but also about the two sciences (now called religious and secular). Since enlightenment cannot be achieved by denying faith, faith and belief are the basis of any enlightenment.

It is narrated on the authority of Abu Darda that the Prophet (peace and blessings of Allaah be upon him) said: "Whoever seeks knowledge, Allaah will make the path to Paradise easy for him. Of course, the seeker of angels puts his wings to please science. Of course, the celestial beings, the earthly beings, and even the fish in the water apologize to the scientist. The phase of the scientist's monument is similar to the phase of the moon from other stars. Of course, scholars are the heirs of the prophets. Of course, the prophets did not inherit a dinar or a dirham. Of course, they inherited science. He who receives it receives a great reward. " Apparently, the prophets did not inherit either a dinar or a dirham, they only inherited knowledge. Therefore, scholars are the heirs of the prophets. Because they possessed the knowledge left by the prophets.

During the study, based on the tasks set by the President on the formation and development of "Higher Education without Corruption", a model of "Higher Education without Corruption" was developed and the factors of its formation were indicated. In addition to the many factors that promote the development of our society, ensure its effective functioning, there are also factors that negatively affect its development, creating insecurity in the psyche of people. One of them is that the scourge of corruption still persists. The impact of this negative factor leads to not only economic but also significant spiritual decay. As a result, the political situation may deteriorate. As a result, it will be necessary to completely eliminate the elements of corruption not only in all areas of education. As the President said in his Address to the Oliy Majlis on January 24, 2020: . We need to move from fighting the effects of corruption to preventing it at an early stage" [6]. One of the important factors of this is the need to bring science and faith together, to ensure the harmony of science and enlightenment.

All current efforts to develop the education system are aimed at completely freeing the system from the scourge of corruption in the future. This issue has risen to the level of top priorities in the implementation of reforms in education. Achieving "higher education without corruption" is considered one of the most painful points in our society. It is true that solving this problem has become one of the most pressing tasks today. Elements of corruption were mainly observed in university entrance exams. This has been virtually eliminated in recent years as a result of ensuring the transparency of the process of taking entrance exams.

As noted by the President, entrance exams to higher education institutions will be further optimized. In particular, in his address to the parliament, the head of state said: "We need to 
focus on simplifying the process of admission to the university, to get real knowledge and education in higher education." Our life has shown that where there are elements of corruption, there will be no quality of work, the environment of justice will be disrupted. These have a very negative effect on the human psyche. Where there is no justice, people lose confidence. People who have lost trust cannot be satisfied with anything.

In order for a person to remain a saint and a saint in society, what is required of everyone to meet the demands of today's stage of development is faith, knowledge and discipline. A believer certainly lives in pursuit of knowledge. A man of faith and knowledge will surely be disciplined. If a person is a believer and has mastered the science of Islam, the five daily prayers themselves will encourage anyone to be disciplined and will absorb this habit. He should perform every prayer on time. It cannot be read before, nor can it be read after a certain period of time. A person accustomed to this becomes accustomed to doing things in life in addition to prayer on time.

This example also shows that faith, knowledge and discipline are inextricably linked. Sufficient success can be achieved even if a person with all three works or works in the higher education system. In particular, a faithful, knowledgeable and disciplined educator will not allow corruption. Can self-manage. Justice is not violated in a non-corrupt education process. Where there is justice, there is success. The interdependence of these processes is shown in the following figure (Figure 1).

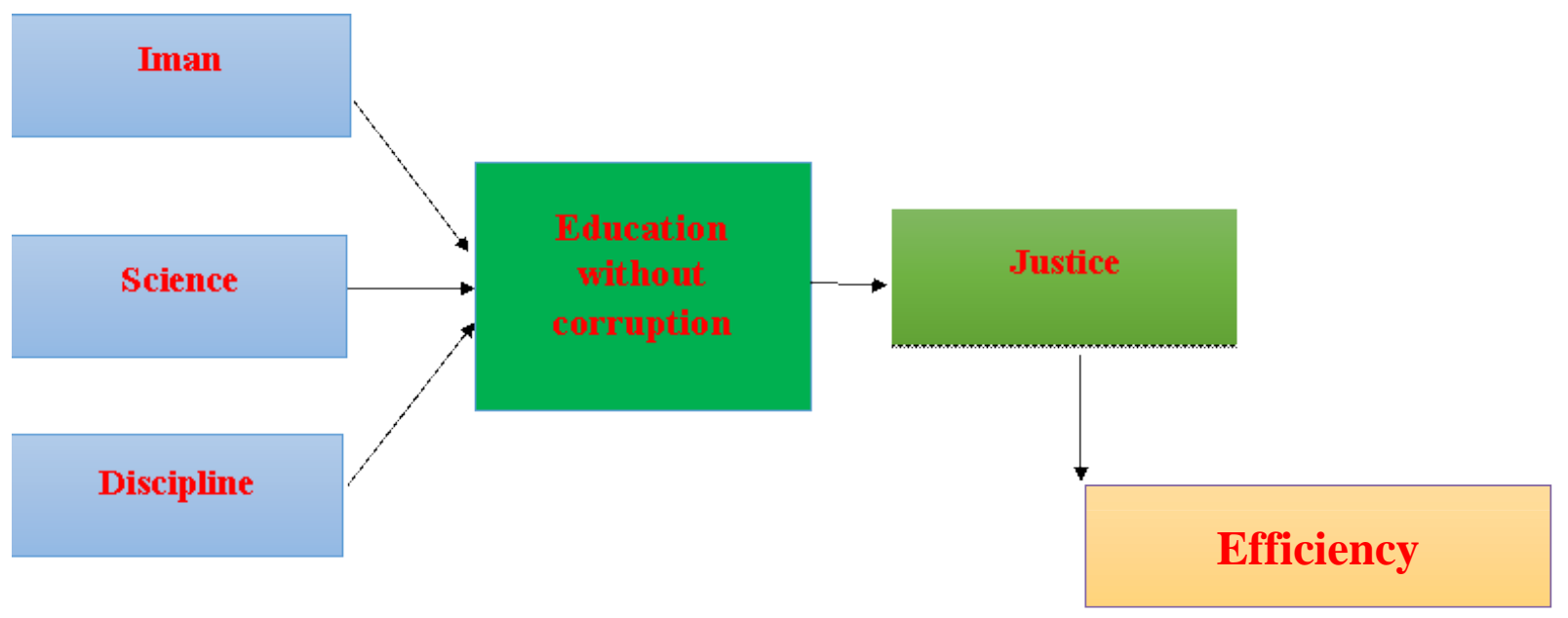

Figure 1. A model for shaping higher education, ensuring justice and efficiency without corruption

As you can see from the picture, in order to be effective, you must first be a faithful, knowledgeable and disciplined educator. Among these elements of efficiency are "Education without Corruption" and justice. This connection also shows that the beginning of all success is due to the presence of people of faith, knowledge and discipline. It's the same for everyone, whether it's an educator, a leader, or a parent of a student. Admittedly, in some cases, parents are also responsible for corruption in education. This is because parents often "run" so that the child does not suffer and gets a light grade. A parent who loves his child should first and foremost strictly 
control his reading. Instead, they "feel sorry" for their child, mislead him, and make him "lame."

As a result of the research, scientific and practical recommendations were developed on the main directions of higher education reform. In his address to the parliament, the President said: "We must carry out large-scale work on priority development and reform of the areas identified in the name of 2020." [7], he pointed out. What these priorities are is clearly stated in both the appeal to parliament and the concept for the development of the higher education system until 2030.

\section{CONCLUSIONS AND SUGGESTIONS}

Based on the priorities set out in the reform of the higher education system outlined in the above documents, a number of issues need to be addressed. We found it necessary to focus on these priorities and what measures should be taken in the field of education in order to address the pain points in today's higher education.

First, one of the top priorities for success in higher education will be the introduction of strict discipline in it. Where there is no discipline, neither knowledge nor education will succeed. Where there is no discipline, time is wasted. It's hard to imagine how much time lost is worth when we realize that every moment is precious. Time is such a blessing that it cannot be restored. Now, by "locking" 50 students in one auditorium, a teacher who has not been able to teach an effective lesson will lose a total of 50 minutes, as well as the time of 50 students. Discipline is not limited to just starting a lesson on time and finishing it on time. It is also related to the fact that each professor and student performs their duties in a truly prescribed manner. As soon as the demand comes for a full lesson, he has to take extra lessons to shed the knowledge. Even if he does not do so, he will be violating the discipline of education. This is also a big loss. Discipline is a very broad concept that must be formed in a person's inner psyche. It is this situation that requires the harmony of science and faith.
Second, higher education should not be limited to theoretical knowledge. It is necessary to ensure the compatibility of theory and practice. This requires each university to have laboratories and experimental sites equipped with advanced equipment in their field. For example, the Samarkand Institute of Economics and Service operates as a pilot site on a contract basis with leading hotels in the city. It has a kitchen, which prepares national dishes and provides high-quality service. There is a tourism company at the institute. The Department of Banking has pilot branches of several commercial banks located in the region, and, accordingly, students conduct practical classes directly in banks. A similar situation can be observed in the classes held at the Department of Marketing. The department of accounting has an audit firm and consulting firms. There is a leadership course at the Department of Management, Economic Analysis and Statistics. The Samarkand School of Economics, which generalizes scientific research and teaches current scientific work, also operates. In these experimental sites, the combination of theoretical knowledge with practical skills is ensured. But these are still not enough to ensure a complete harmony of science and practice. This activity will need to be further expanded.

Third, it is necessary to organize training in higher education institutions on the basis of special orders of relevant government agencies and organizations, as well as entrepreneurs. Then most students 'jobs will be clear until they graduate. Importantly, they also know where to work tomorrow and what sciences to focus on. It is precisely this enterprise where the student goes through all the internships. In this case, they are able to ensure the compatibility of theory and practice while graduating from university. He not only reads, but acquires knowledge in-depth in accordance with the demand of the customer. But much remains to be done in this regard. Work on this issue began in the 2019/2020 academic year. This will need to be expanded and improved. Students who study voluntarily without an order 
will need to be brought to a level of selfemployment. After graduating from high school, he shouldn't have to worry about where to go to work. Another important aspect is that a student will be forced to take a diploma in one specialty and work in a completely different field if he or she does not have a job in that field. This is a great loss for both the student and the community. A single professional who benefits the community in his or her field means that he or she is "lost" in vain.

Fourth, the higher education system must have a price and market for intellectual property in order to solve the problem of intellectual property commercialization, which combines education, science, innovation and research. Today, the market and price of material goods are clear. Due to this, the industry is developing in line with the development of society. But shaping intellectual property is not an easy task. It is achieved through the hard work of people over the years. However, the lack of appreciation for this work is one of the factors hindering its development. For this reason, first of all, it is necessary to develop a Charter that determines the value of intellectual property, and then it is possible to shape their market. Scientists and scientists are the ones who come up with a problem in society, develop recommendations for its solution, and then "beg" to put this work into practice. Due to this, people are not interested in this scientific work, in owning intellectual property. At present, our scientists are only interested in working in this field due to the increase in their monthly salary. But we have a lot of shortcomings here as well. There are different intellectual property owners. But the difference between paying them is inconsistent with the difference in that intellectual property. In this regard, the head of our state in his address to the parliament said: "We will introduce a system of high salaries for teachers who have the level of pedagogical skills and qualifications, who have achieved concrete results in their work." Now is the time to value intellectual property.
Fifth, the structure and order of teaching in the higher education system also need to change. Current programs at the university are mainly focused on becoming a specialist, working in an organization tomorrow, working in existing offices, enterprises and institutions. At present, if the enrollment rate of young people in higher education is increased to 50-60, not all of them will be able to find a job in the existing offices, enterprises and institutions after graduation. There are no vacancies in government organizations every year. Entrepreneurs will also continue to operate with relevant jobs. The new jobs created in them do not fully meet this need. In such conditions, it is necessary to prepare graduates for independent living on the principle of selfemployment, creating new jobs for themselves and forming the ability to live on this basis. In this case, if each graduate creates a job for himself, almost as many jobs will be created. If he creates two jobs, he will hire another person. We think it is time to prepare young people with higher education in this direction.

Sixth, another important aspect is the issue of educating students as highly qualified personnel. It is as necessary as water and air for our development today. But it is difficult to answer the question of whether we have enough teachers to train such personnel. The educators of today's generation are made up of people who were formed at a time when educators were ignored. Many students who graduated well went on to other fields, some abroad. Because of this, current educators have not been accepted with great competition. Because of this, it must be admitted that some of our educators are lagging behind in the dramatic changes taking place in our society. Of course, these continue the old teaching, the transition of drars with old knowledge. In this way, graduates of higher education institutions are awarded diplomas but cannot impart knowledge. I think it is time to put very high demands on the qualifications and level of teachers. Everyone has great scientific and intellectual potential. These need to be activated. 
Today's demand will be met only if everyone works on himself and constantly improves himself and his work. Due to this, strict discipline, scientific environment, the spirit of great responsibility must be formed in every university, in every pedagogue. As the head of our state noted in his address to the parliament, every educator should have a real enlightenment and high culture, and these qualities should become a constant vital need. Only then will we be able to achieve the high goals set by our President.

Seventh, higher education institutions will be gradually given academic and financial independence. This event will create a healthy competitive environment among universities. Competition is also one of the important factors of development. In his address to the parliament, the head of state said: "Higher education institutions will be gradually given academic and financial independence. This year, 10 of them will switch to self-financing. In addition, we will select at least 5 higher education institutions on a competitive basis and begin their transformation in cooperation with prestigious foreign higher education institutions. " At present, according to the decision of the Cabinet of Ministers, 10 universities have switched to self-financing. Among them is the Samarkand Institute of Economics and Service. Today, the school is estimating all its possibilities and forming its plans. In general, there is already confidence that the results of the work done as an experiment will be good.

In short, 2020 will be a year of special responsibility for all of us, a year of testing and mobilization for everyone. Because it is impossible to occupy the high marrals defined by the old style of work and the attitude towards it. It requires all of us to approach our civic duty with an entirely new responsibility. After all, today's Uzbekistan is not yesterday's Uzbekistan, today's growth rates are not the same as yesterday, and our people today are not yesterday's people. Our people today are a nation that feels the democratic process, abandons indifference and takes on the burden of responsibility. May the Creator Himself support our efforts to please such a people.

\section{REFERENCES:}

[1] Address of the President of the Republic of Uzbekistan Shavkat Mirziyoyev to the Oliy Majlis on January 24, 2020.// "Xalq so'zi" newspaper. January 25, 2020. No. 19. 2 pages.

[2] Human development. Textbook. Edited by I.f.d., Professor Q.H.Abdurahmanov. - T .: "Science and Technology" Publishing House, 2013. - 476 pages, Pardaev M.Q. The digital economy is the future of the country's development. // "Service" scientific-practical journal. 2019. Number 3. Page 7, Pardaev, M.Q., Mirzaev Q.J., Pardaev O.M. Service sector economics textbook. - T .: "Economy and Finance", 2014. - 384 pages., Adilova Z., Khanto'raev B. The role of science and education in the development of the digital economy. // Problems of development of the service sector in the conditions of innovative and digital economy. (February 21-22, 2020) Materials of the International IAC, Samarkand-Tambov, 2020. - pp. 16-19., Isroilov BI, Gadoev EF. An Explanatory Dictionary of the Concept of AntiCorruption and Anti-Corruption Terms. - T .: "Tafakkur" publishing house, 2019 .. - 168 pages. Isroilov B.I. Issues of preventing corruption in the education system. // Problems of development of the service sector in the conditions of innovative and digital economy. (February 21-22, 2020) Materials of the International IAC, Samarkand-Tambov, 2020. - pp. 183-186.

[3] Decree of the President of the Republic of Uzbekistan PF-5847 "On approval of the Concept of development of the higher education system of the Republic of Uzbekistan until 2030" adopted on October 8, 2019

[4] Address of the President of the Republic of Uzbekistan Shavkat Mirziyoyev to the Oliy 
Majlis on January 24, 2020.// "Xalq so'zi" newspaper. January 25, 2020. No. 19. 2 pages.

[5] Address of the President of the Republic of Uzbekistan Shavkat Mirziyoyev to the Oliy Majlis on January 24, 2020.// "Xalq so'zi" newspaper. January 25, 2020. No. 19. 4 pages.

[6] Address of the President of the Republic of Uzbekistan Shavkat Mirziyoyev to the Oliy Majlis on January 24, 2020.// "Xalq so'zi" newspaper. January 25, 2020. No. 19. 2 pages.

[7] Mamatova Ya., S. Sulaymanova, Uzbekistan on the way to the development of media education. Study guide. $-\mathrm{T}:$ «Extremumrress», 2015. - 94 p.

[8] Pardaev M.Q. The digital economy is the future of the country's development. // "Service" scientific-practical journal. 2019. Number 3. Page 7,

[9] Pardaev, M.Q., Mirzaev Q.J., Pardaev O.M. Service sector economics textbook. - T : "Economy and Finance", 2014. - 384 pages,

[10] Saidov M.Kh. Uzbekistan: investments and human capital, partnership in the field of education. - M.: Book house of the newspaper "Trud", 2008, - 362 p.,

[11] Xoliqov A. Pedagogical skills. Study guide. Tashkent "Economy and Finance". 2010. p.8,

[12] Sheikh Muhammad Sadiq Muhammad Yusuf Social Etiquette. - T .: "Nihol-Nashr", 2013. - 356 pages. 